\title{
OUTSOURCING FAILURES IN SME'S: CASE STUDY APPROACH
}

\author{
Kaja Prystupa, Maciej Rządca \\ Koźmiński University, Warsaw, Poland \\ E-mail: kmprystupa@alk.edu.pl, mrzadca@alk.edu.pl
}

\begin{abstract}
Outsourcing, which is a popular business strategy among large companies, is also an attractive option for small entities. However, in order to bring expected results, outsourcing requires knowledge of potential risks and ability of managing them. Even large companies need to face various outsourcing challenges, however, at least they dispose richer resources than small organizations and their success is less dependent on single product delivery. Therefore the aim of the research was to examine the reasons of failure of outsourcing initiatives in SMEs. The authors followed the qualitative approach based on case study method. The obtained results brought contributions in both areas: theoretical as the issue of outsourcing initiatives in SMEs has been analysed to a limited extent; as well as practical because it brought important insight for managers by indicating risks of that they should be aware and properly prepared. The findings indicated the importance of: strategic planning on outsourcing initiative and the development and maintenance of close relations of outsourcing companies with its vendor.
\end{abstract}

Key words: case study, outsourcing in SME, outsourcing challenges, small companies.

\section{Introduction}

Outsourcing has become a popular strategy for companies worldwide. As a strong force in the global economy, it reshapes businesses (Boguslauskas \& Kvedaraviciene, 2009). Under such a trend, various organizations decide to rely on external vendors in order to lower costs, ensure higher quality and flexibility, and gain access to superior technical resources (Antonucci, Lordi, \& Trucker, 1998; Tafti, Sledgianowski, \& Kierstead, 2008). Moreover, they may gain a competitive advantage through a partnership by sharing information and knowledge (Fish \& Seydel, 2006).

\section{Problem of Research}

Most of the extant research has concentrated on outsourcing in large organizations (Busi $\&$ McIvor, 2008). However, for a decade, it has been gaining popularity among small enterprises (Antonucci et al., 1998). Managers of SMEs are developing increasing interest in launching outsourcing activities due to the challenges of growing global competition and dynamic market changes. According to Mehta \& Peters (2007), for small companies, outsourcing is not a choice but a requirement, as they often cannot afford to build up internal resources with the required skills and efficiency. As outsourcing has become more popular, organizational decision makers need information that will help them to establish and maintain sustainable relations with their vendors (Kremic, Tukel, \& Rom, 2006). In particular, the launching and maintenance of outsourcing is associated with various risks, such as the loss of expertise, hidden costs, limitation of control, loss of privacy and security, and loss of morale among employees (Antonucci et al. 1998; Tafti et al., 2008). Therefore, outsourcing requires strategic planning and implementation. Large organizations dispose necessary resources, which they can use in order to prepare themselves for the launch of an outsourcing initiative. Small enterprises, often suffer from 
Kaja PRYSTUPA, Maciej RZĄDCA. Outsourcing failures in SME's: Case study approach

PROBLEMS

OF MANAGEMENT

IN THE $21^{\text {st }}$ CENTURY Vol. 10, No. 1, 2015

scarcity in terms of human and financial resources as well as knowledge, which may hamper the outsourcing success. Additionally, their failure is much more dangerous, as it is easier to endanger the stability of the whole organization than in the case of large organizations.

Therefore, the aim of this research was to examine the reasons of failure of outsourcing in small companies. The results of qualitative research based on in-depth inquires of product development in two software companies. The author followed the case study approach, as it provides deep understanding of the consequences of the actions of both individuals and organizations (Lincoln \& Guba, 2002). The analysis of unsuccessful outsourcing initiatives provides greater insight into factors that threaten their success.

\section{Research Focus}

Outsourcing is defined as an action or practice of obtaining goods or services by contract from outside sources (Boguslauskas \& Kvedaraviciene, 2009). From the current perspective, this concept is perceived as a strategy of a company that facilitates greater focus on core business interests through the redirection of the company's vital resources and disposal of less important ones to a vendor (Brandes, Lilliecreutz \& Brege, 1997; McIvor, 2000; Moran, 1997; Prahalad and Hamel, 1990). Having been perceived as a side activity, outsourcing has been developed to be of strategic importance for the company's existence (Boguslauskas \& Kvedaraviciene, 2009). Therefore, its implementation requires careful consideration and planning.

The outsourcing decision has to be preceded by the development of a strategic outsourcing plan in the context of business strategy (Boguslauskas \& Kvedaraviciene, 2008). The company has to evaluate its processes and sources of information that feed into them (Boguslauskas \& Kvedaraviciene, 2009). The outsourcing failures are not due to an inherent problem with outsourcing, but rather the lack of guiding methodology for managers (Lonsdale, 1999). According to Robinson Kalakota, \& Sharma (2005), the strategic plan may be developed by answering following questions:

- Which processes should be outsourced?

- When should these processes be outsourced?

- Where should they be outsourced to?

- How should they be outsourced?

Various studies have indicated that essential to successful outsourcing is proper identification of core competences that relate to "collective learning in the organization, especially how to coordinate diverse production skills and integrate multiple streams of technologies" (Prahalad \& Hamel, 1990, p. 81). Only non-core competencies should be outsourced (Brown \& Wilson, 2005; Boguslauskas \& Kvedaraviciene, 2009), as otherwise the company may lose its competitive advantage. However, proper identification of core competencies is not easy, as it is developed through the combination of knowledge, skills, technologies, operation methods, and various underestimated information, which are available in the organization (Greaver, 1999). "Too many companies have unwittingly surrendered core competencies when they cut internal investment in what they thought were just 'cost centres in favour of outside suppliers' (Prahalad, Hamel, 1990, p. 84). If organizations outsource the wrong functions, they may develop gaps in their learning or knowledge base, which may preclude them from future opportunities (Earl, 1996; Prahalad \& Hamel, 1990). If the function provides critical knowledge, it should not be outsourced (Kremic et al., 2006). The company must be able to manage the outsourced function inside the company before it is outsourced, because weak management inside will not be corrected by outsourcing its services (Earl, 19960).

There are several characteristics of function that influence the decision regarding whether it should be outsourced. Firstly, a function that is more structured and more complex should be left in-house (Tafti, Sledgianowski, \& Kierstead, 2008; Kremic, Tukel, \& Rom, 2006). Sec- 
ondly, the level of integration with other companies' operations should be moderate or low. Highly integrated functions require more interaction and communication, which is difficult to achieve across organizational lines (Kremic, Tukel, \& Rom, 2006).

The proper selection of a vendor is vital. The wrong choice may create a risk to the success of outsourcing itself, as the vendor may not have personnel with the relevant expertise or may be using older IT systems, which could trap customers within outdated technology (Earl, 1996, (Kremic et al., 2006). If the organization is recognized in the industry for a high level of quality, then outsourcing may be perceived as a form of potential risk (Anderson, 1997). The additional risk arises when the applied technology has not been used by the vendor in prior projects (Verner \& Abdullah, 2012).

The establishment of an endurable relationship between the company and the outsourcing vendor is vital for the company's overall success (Brandes et al., 1997; Tafti, et al., 2008). The organization of networking events for both sides can facilitate the establishment of close relations (Tafti, et al., 2008). The vendor and outsourcing company need to learn each other's corporate culture and organization relationship (Earl, 1996). Clear communication between both parties is vital. The vendor's project leader should learn and fully understand the company's outsourcing needs and objectives (Tafti et al., 2008).

Another important aspect is the development of a contractual agreement between the user and vendor, in which all terms and conditions should be regulated (Takac, 1993). On the other hand, due to the rapid changes in technology and implementation surprises, it is better to pay more for flexibility than to specify tight performance contracts with penalty clauses (Earl, 1996, Verner \& Abdullah, 2012). The outsourcing contract should be detailed and comprehensive, but good-faith partnership and mutual trust are also critical to outsourcing success (Tafti et al., 2008). The ownership of the value created during the collaboration of client with the vendor should be agreed upon by both sides. The outsourcing company needs to set precise measurements to evaluate the effects of collaboration with the vendor (Pisanias, Graeser \& Willcocks, 1999; Verner \& Abdullah, 2012). It has to decide about the total amount that can be spent on the outsourcing. When the limit is exceeded, the company should make the decision to cancel the project (Verner \& Abdullah, 2012).

The contract should regulate financial aspects in detail. Those which created the greatest risk are: hidden costs, currency exchange fluctuations, and insufficient funds (Verner \& Abdullah, 2012).

Maintenance of good relations between the vendor and outsourcing company is vital for the success of the collaboration. According to Bairi \& Manohar (2011), in order to develop a fruitful outsourcing partnership, the vendor must:

- develop ground rules for collaboration;

- $\quad$ be reliable and keep promises;

- $\quad$ assist the outsourcing company in problem solving;

- $\quad$ keep the outsourcing company informed about progress/issues;

- listen to the problems of the outsourcing company.

Tafti et al. (2008) suggested that the maintenance of good relations between both the vendor and the outsourcing company is easier when both organizations are about the same size. 
Kaja PRYSTUPA, Maciej RZĄDCA. Outsourcing failures in SME's: Case study approach

PROBLEMS

OF MANAGEMENT

IN THE $21^{\text {st }}$ CENTURY
Vol. 10, No. 1,2015

40

\section{Methodology of Research}

\section{Research Design}

The aim of this research was to examine the reasons for failure in outsourcing among small companies. Qualitative analysis of the collected data has been conducted in accordance with the case study method (Yin, 2003), including guidelines concerning the development of research protocols, case study databases, triangulation of sources, and maintenance of strings of evidence from the result to the original data. The chosen approach facilitates examination of "how" and "why" (ibid.), which are crucial in the process of examination of decisions making reference to the establishment and maintenance of outsourcing by small companies. Qualitative research allows a researcher to generate detailed information, since richer answers to questions can be obtained from the subjects being studied (Lincoln \& Guba, 2002).

According to the case study method, the choice of the unit of analysis is subordinated to the purpose of research (Yin, 2003). Hence, it is not random, but instead is a result of a conscious selection process. While selecting the entities suitable for the research, the author followed the definition of SME developed by the European Commission in 2003. According to the Recommendation a microenterprise is defined as the company that employs less than 10 individuals with annual turnover less than 2 million euros. Both selected organizations prior to the commencement of outsourcing activities were successful on the market. SVX-1 was the producer of the most popular Polish antivirus in the 1990s. As recalled in the press, "It was hard to find someone, that time who didn't have this software - at least a shareware version of it"'. GFT-1, after two years of learning through errors and mistakes, developed the game that later was bought by the publisher for 250 thousand dollars and received numerous awards.

\section{Instruments}

The basic techniques of data collection were semi-structured interviews with the companies' management, analysis of documentation, press materials, and (in the case of Power Media) the blog of one of the co-owners. Blogs are particularly useful in qualitative research, as they allow researchers to examine the social processes over the time, providing insight into the everyday lives of the team members (Hookway, 2008). Researchers gathered around 200 pages of materials in total.

\section{Data Analysis}

Following a grounded theory, the authors discovered dominant categories and their characteristics (Charmaz, 2009). The data were coded using the open coding technique (ibid.). Subsequently, it was analysed with the software Dedoose, dedicated to qualitative research. To maintain the credibility of results, the authors used the data triangulation method (Denzin, 1978), which allowed for the development of the dominant themes of research.

The identities of the interviewees as well as the products that appeared in the article were changed according to the agreement between the researcher and the organization under study.

$1 \quad$ Citation from press. 


\section{Results of Research}

SVX-1 was the first Polish company that produced antivirus software on the local market. The company was founded by Theodore Kowalski in 1996. He developed the first software in 1988 because there was no antivirus software available for individual computer users. It soon became the most recognizable software on the local market. The company had the biggest share of the Polish market reaching approximately $40 \%$. It quickly extended its product portfolio, offering software to corporate clients. However, since 2000, SVX-1 had begun to lose part of the corporate market as the alternative programs begun to appear. It was a relatively small market, as it concerned only Polish companies, because subsidiaries of western corporations operating in Poland mainly used the programs recommended by their headquarters. The biggest competitor of SVX-1 was Symantec, which was at that time primary anti-virus software among foreign companies in Poland.

On March 2003, Theodore died. His son, Eusebius (21 years old), the oldest in the family, had to take over the management of the company. The legal situation of SVX-1 was complicated, as it involved 7 heirs, only two of whom were adults (i.e. Eusebius and Lara, his stepmother). The former president of SVX-1 (Leon), who was an old friend of both Theodore and Eusebius, decided to take over the market and set up a new company, launching a new business competitive to SVX-1 only 3 months after Theodore's death. He used the disagreements between Eusebius and Lara and begun to persuade the existing customers of the company to choose products of the new one, BitVir.

At the end of 2005, owners of SVX-1 found out what had happened and took action to improve the functioning of the company. Eusebius decided to employ Louis, an experienced managing director. At the same time, 15 members of the development team decided to cease cooperation with SVX-1, as they were offered positions at BitVir.

In-house software development with a limited number of employees would take too long; therefore, Louis along with Eusebius decided to employ a third-party provider that would provide specialists. Eusebius had little experience in the management of programmers and the software market in general. However, he wanted to continue his father's work. Another problem was the lack of software in the company.

There was no SVX-1 program. They were source codes, but they weren't complete. The company had to restore control over its product. (Eusebius)

The software development market in Poland was small, so the SVX-1 management followed the recommendations of some programming specialists, while selecting the outsourcing vendor that would develop new software. Quickly they signed the contract and delivered requirements to the development team. Unfortunately, after a while it turned out that the SoftGal did not have the relevant knowledge in the field of detecting viruses. For instance, they did not know how to use the relevant algorithms for virus detection. As a result, parts of the software were developed too quickly with many bugs and errors. Moreover, no one was checking software releases after every update and add-ons to virus databases as they were released on Friday afternoon. They were checked over the weekend, when potential errors and software problems were already appearing. Quality control in SoftGal was poor, while SVX-1 had virtually no internal quality at all, because of the lack of human resources. However, the SVX-1 management could not punish SoftGal, as the contract specified that the subcontractor would be subjected to financial punishment only in case of delays and not for the poor quality of delivery. Customers became angry about the poor product quality. SoftGal programmers focused primarily on the visual side of the program; they had neglected issues related to tests of additional parts of the source code and search heuristics mechanisms of viruses. The software was working very slow- 
Kaja PRYSTUPA, Maciej RZĄDCA. Outsourcing failures in SME's: Case study approach

PROBLEMS

OF MANAGEMENT

IN THE $21^{\text {st }}$ CENTURY

Vol. 10 , No. 1,2015

ly. Quickly, SVX-1 was taken ahead by the company's competitors. After a while, the company ceased its outsourcing processes and tried to develop its own development team. However, the damaged reputation led the company to bankruptcy.

\section{GFT-1}

GFT-1 was a Polish game development company which dedicated its products to a niche segment of hidden object games (which is part of the casual games market). It was officially launched in 2004 by two friends, Chris and Mark, one year before their graduation from the university. However, the young entrepreneurs were engaged in game development much earlier. Since high school they dreamt of working in the gaming industry as producers. Therefore, during their studies, they made several attempts to gain recognition in the market. They used the advantage of market changes; i.e. the emergence of online distribution through gaming portals. The first two games that they developed turned out to be failures. The first time, their game concept turned out to be too ambitious, and they were unable to complete the product. They had insufficient resources, both financial and human. During their second attempt, they took into account their experience and designed a smaller game. The reason for its failure was the mismatch to market preferences; i.e. usage of very innovative technology which was still inaccessible for many gamers, and a high level of difficulty within the game, which discouraged many players. However, the third game, Myth, revealed to be a major success, as it received 3 different awards (inter alia for its sophisticated gameplay). Chris and Mark sold the property rights to a famous American publisher for 250 thousand dollars. They felt that they did not have enough financial resources and knowledge to properly advertise their product, and this sale was a relatively safe and profitable solution. The development of Myth brought valuable knowledge and experience to Chris and Mark. First of all, they learnt how to acquire and interpret information about customer preferences. Secondly, they became familiar with all elements of game development, as they produced everything by themselves. They dealt with design, graphics, programming, sound and music recording, and testing. Chris and Mark invested money obtained from the Myth acquisition in the launch of GFT-1, in which they employed two graphic designers and two programmers. The everyday management of the company appeared to be difficult for the young producers. Due to the high costs of game development and the maintenance of a development team, the entrepreneurs had to look for more stable sources of income. The development of a game was taking them at least 12 months. Their savings revealed to be insufficient to ensure the company's liquidity. Chris and Mark decided to conduct the development of two games simultaneously. Their market analysis showed them new interesting trends the company could use to leverage its resources. However, due to limited human resources, they decided to outsource the development of one of the games to another development studio. The additional premise to outsource was the fact that market trends were swiftly changing. Therefore, swift product development was vital. Chris and Mark knew the Polish game development market quite well; it was relatively quite small and "everyone knew each other". Therefore, having established connections on the market, they decided to employ a local development studio, Flemings. This studio was established by experienced developers, former employees of the one of the most famous game development companies. On the Polish market it had developed credentials while fulfilling orders for the biggest Polish game designers.

According to the contract with Flemings, the game was set to be ready in 4 months. When the GFT-1 owners received the first version of the game, they were disgusted by its low quality and considered dropping the project. However, the outsourcing company assured them that the project would be completed according to their guidelines. Mark said: 
"Later, such considerations would become a recurring motive of every delivery. Anyway, from today's perspective, we know that dropping the project at this early milestone would probably be a good choice, but back then nothing was so obvious. (...) Dropping a project is like giving up and making a conscious decision to lose all the potential profits. The more time and money you invest in a project, the harder it is for you to abandon it."

After eleven months of unfruitful cooperation, Chris and Mark decided to stop the project, as Flemings was unable to deliver the product on time with the requested quality.

They obliged Flemings to finish the "functional part" of the game, and "the quality part" was developed in house.

“It was unplayable. (...) It was functioning, but it didn't deliver pleasure. It was underdeveloped. The outsourcing company produced it according to specifications, so it was working more or less. All parameters dealing with game design, not technical aspects, were crappy" (Greg, game designer).

It took 7 months and two dedicated employees to finish the game. The programmer worked on fixing bugs and improving the game, whereas the game designer introduced many changes to the game's balance.

Finally, when the game was launched, it did not bring the estimated results. One of gaming portals even refused to publish it, pointing out that they prefer more fashionable products. Mark summed up the experience of outsourcing of game development:

"The basic mistake was on our side. We shouldn't have outsourced the game's development to a company that had no prior experience in creating casual games. But then again, Flemings knew how to advertise itself and knew exactly what we wanted to hear. We were sure that they knew what they were doing."

\section{Discussion}

The presented cases indicated several reasons for the failure in the outsourcing initiatives which were the consequences of the companies' behaviour at both stages - prior to launch of outsourcing and at the time of outsourcing.

Both companies lacked strategic planning of outsourcing process (Robinson et. al., 2005). As a result, at the stage of project development, they outlined unclear requirements which caused problems with proper calculation of time and cost (Verner \& Abdullah, 2012).

Lack of strategic analysis prior to the launch of outsourcing resulted in transmission of processes to the vendor that constituted the basis for the companies' core competences. The core competence of SVX-1 was the superior virus detection, whereas in the case of GFT-1, sophisticated gameplay. Smaller companies often are unaware which tasks belong to the core competencies (Metha \& Perers, 2007) and skip the analysis of organizational processes prior to launch of outsourcing (Robinson, et al., 2005; Yap, Lim \& Lee, 2013). The unique mix of knowledge, skills, and other attributes are difficult to imitate (Boguslauskas \& Kvedaraviciene, 2009), and those elements were vital for successful product development in both companies. Many crucial aspects of product development were tacit knowledge; i.e. game balance. The transfer of such knowledge, even in the organization, is complicated, not to mention the crossboundary transmission (Lubit, 2001). By outsourcing those functions, the companies were unable to perform arms-length monitoring (Metha \& Perers, 2007) in which they could provide the necessary guidance. 
Kaja PRYSTUPA, Maciej RZĄDCA. Outsourcing failures in SME's: Case study approach

PROBLEMS

OF MANAGEMENT

IN THE $21^{\text {st }}$ CENTURY

Vol. 10, No. 1,2015

The outsourced processes were too complex to be outsourced. Additionally, they required close integration with other organizational functions in order to be successfully completed (Kremic et al., 2006). However, such an approach was missing, which caused problems with product delivery and maintenance of its high quality. According to Tafti et al. (2008), the outsourcing should have initially involved fewer tasks that do not require a high level of expertise. However, in both presented companies, they decided to transmit to the vendor the advanced functions straight away.

SVX-1 and GFT-1 were well-recognized producers; therefore, the decision to outsource was rather risky (Anderson, 1997). In order to manage the risk, they conducted an analysis of the potential vendors. The decisions to employ a particular vendor were based on the advice of other market participants and general opinion that they found expressed through various media. For instance, GFT-1 signed the contract with Flemings because it admired the work of the company's co-owners that was created in their previous workplace. However, the information gathered by the companies was not verified by multiple sources (Verner \& Abdullah, 2012).

The employed vendors lacked specialists' expertise in the fields of anti-virus software development (SVX-1) and the development of hidden objects games (GFT-1), despite having a good reputation on the market (Earl, 1996; Tafti et al., 2008; Verner \& Abdullah, 2012). Both market sectors (anti-virus software and game development) in Poland were relatively young, and such knowledge was rare and unique. It was impossible to easily transmit it across organizational boundaries (Kremic et al., 2006).

SVX-1 and GFT-1 signed a general contract with vendors; i.e. it did not include their market specifics (Earl, 1996). Both companies focused on time delivery and not on the quality of products and the changing market needs. In the case of GFT-1, the market trends were changing so fast that the delay in product development undermined the whole idea of the product's existence. Both companies did not introduce special measures to control vendors (Pisanias et al., 1999). Additionally, they did not pay attention to the signs that indicated that the vendors were not suitable for the given tasks. SoftGal and Flemings had problems keeping promises and, during product development, they often were unable to solve problems on their own (Bairi \& Manohar, 2011). SVX-1 and GFT-1 were unable to decide to cease cooperation when faced with such indications (Verner \& Abdullah, 2012). Instead of the assessment of vendors' work at the initial stages of product development (Earl, 1996), they trusted the general opinion of the companies.

SVX-1 and GFT-1 did not develop close relations with their vendors that would enable them to learn their corporate culture and gain understanding of their organizational processes (Earl, 1996). They were meeting with them at the end of each milestone. Scarce communication hindered the development of complete understanding of customers' needs and objectives (Tafti et al., 2008). As SVX-1 and GFT-1 were small companies delivering moderate profits for vendors, they were not given special attention. Being treated as "regular" clients meant, however, that the vendors did not attempt to understand their specifics and did not offer customized service (Tafti et al., 2008).

The outsourcing should not be treated as a cure for the poor management of a company (Earl, 1996). However, this was the case in SVX-1, where Eusebius lacked necessary experience in management and the company was partially paralyzed by divided ownership. If the management is not able to control the process internally, it will not be able to gain control from a distance. The owners of GFT-1, despite their experience in game development, faced challenges when the company was created and needed to manage a team. 


\section{Conclusions}

Despite the various advantages of outsourcing, this strategy brings risks and challenges of which the organization may not be aware. For small companies, outsourcing is a tempting solution, as it may allow companies to reach a greater speed of product delivery and serve as leverage. However, the management should take into account the risk associated with outsourcing. The results of the conducted research presented insight into the challenges of outsourcing for small companies. From a scientific point of view, it attempted to fill an important gap in the outsourcing literature. The results presented in the research show that the concepts and patterns which are common among large companies may still be unknown for small entities. For the entrepreneurs, the research results may assist in understanding risk factors that affect such a project so that an effective decision can be taken before the risk manifests itself into problems that can damage the project. The list of potential threats and remedies to them is, however, still open, and future research in this field should be conducted.

\section{Acknowledgements}

This study is a result of a research project "Alternative sources of social capital management practices within organizations" run at Kozminski University and funded by the National Center for Research and Development in Poland.

\section{References}

Anderson, M. C. (1997). A primer in measuring outsourcing results. National Productivity Review, 17 (1), 33-41.

Antonucci, Y. L., Lordi, F. C., \& Trucker III, J. J. (1998). The pros and cons of IT outsourcing. Journal of Accountancy, 185 (6), 26-30.

Bairi, J. B., Manohar, M. (2011). Critical success factors in gaining user customer satisfaction in outsourced IT services. Journal of Enterprise Information Management, 24 (6), 475 - 493.

Boguslauskas, V., \& Kvedaraviciene, G. (2009). Difficulties in identifying company's core competencies and core processes commerce of engineering decisions. Inzinerine Ekonomika-Engineering Economics, 2, 75-81.

Boguslauskas, V., \& Kvedaraviciene, G. (2008). Strategic outsourcing plan and the structure of outsourcing process. Inzinerine Ekonomika-Engineering Economics, (3), 60-67.

Brandes, H., Lilliecreutz, J., \& Brege, S. (1997). Outsourcing - success or failure? Findings from five case studies. European Journal of Purchasing \& Supply Management, 3 (2), 63-75.

Brown, D., \& Wilson, S. (2005). Black book of outsourcing: How to manage the changes, challenges and opportunities. New Jersey: John Wiley \& Sons.

Busi M., McIvor, R. (2008). Setting the outsourcing research agenda: The top-10 most urgent outsourcing areas. Strategic Outsourcing, 1 (3), 185-197.

Charmaz, K. (2008). Constructing grounded theory. Los Angeles, London, Ned Delhi, Singapore: SAGE Publications.

Denzin, M. K. (1978). The research act: A theoretical introduction to sociological methods. New York: MacGraw-Hill.

Earl, M. J. (1996). The risks of outsourcing IT. MITSloan Management Review, Spring.

Edmondson, A. (2011). Strategies form learning from failure. Harvard Business Review, Retrieved 06/02/2015 From: https://hbr.org/2011/04/strategies-for-learning-from-failure

Fish, K. E., \& Seydel, J. (2006). Where IT outsourcing is and where it is going: A study across functions and department sized. The Journal Computer Information Systems, 46 (3), 96-103.

Glaser, B., \& Strauss, A. (1957). Discovery of Grounded Theory: Strategies for qualitative research. Chicago: Aldine.

Greaver, M. F. (1999). Strategic outsourcing: A structured approach to outsourcing decisions and initiatives. New York: AMA publications. 
Kaja PRYSTUPA, Maciej RZĄDCA. Outsourcing failures in SME's: Case study approach

PROBLEMS OF MANAGEMENT IN THE $21^{\text {st }}$ CENTURY Vol. 10, No. 1, 2015

Hookway, N., (2008). 'Entering the blogosphere': Some strategies for using blogs in social research. Qualitative Research, 8 (1), 91-113.

Kogut, B., \& Kulatilaka, N. (2001). Capabilities as real options. Organization Science, 12 (6), 744-758.

Kremic, T., Icmeli Tukel, O., \& Rom, W. O. (2006). Outsourcing decision support: A survey of benefits, risks, and decision factors. Supply Chain Management: An International Journal, 11 (6), $467-$ 482.

Leavy, B. (2004). Outsourcing strategies: Opportunities and risks. Strategy \& Leadership, 32 (6), 20-25.

Lincoln, Y. S., \& Guba, E. G. (2002). Judging the quality of case study reports. In: A.M. Huberman, M.B. Miles (Eds.), The qualitative researcher's companion (pp. 205-215). Thousand Oaks, CA: Sage Publications,

Lonsdale, C. (1999). Effectively managing vertical supply relationships: A risk management model for outsourcing. Supply Chain Management: An International Journal, 4 (4), 176-83.

Lubit, R., (2001). Tacit knowledge and knowledge management: The keys to sustainable competitive advantage. Organizational Dynamics, 29 (3), 164-178.

McIvor, R. (2000). A practical framework for understanding the outsourcing process. Supply Chain Management, 5 (1), 22.

Metha, S., \& Peters, L. S. (2007). Outsourcing core competency. Research Technology Management, 50 (3), 28-34

Moran, H. (1997). Outsourcing forges new management strategies. Chemical Market Reporter, 252 (2), 6-8.

Mullin, R., (1996). Managing the outsourced enterprise. Journal of Business Strategy, 17 (4), 28-36.

Pisanias, N., Graeser, V., \& Willcocks, L. (1999). The neglected success factor. Measuring Business Excellence, 3 (1), 16-19.

Prahalad, C. K., \& Hamel, G. (1990). The core competences of the organization. Harvard Business Review, May-June, 79-90.

Robinson, M., Kalakota, R., \& Sharma, S. (2005). Global outsourcing. Executing on onshore, nearshore or offshore strategy. Alpharetta: Mivar Press.

Sledgianowski, D., Tafti, M., Kierstead, J. (2008). SME ERP system sourcing strategies: A case study. Industrial Management \& Data Systems, 108 (4), 421 - 436.

Takac, P. F. (1993). Outsourcing technology. Management Decision, 31 (1), 25-38.

Wong, K. Y. (2005). Critical success factors for implementing knowledge management in small and medium enterprises. Industrial Management and Data Systems, 105 (3), 261-279.

Verner, J. M., \& Abdullah, L. M. (2012). Exploratory case study research: Outsourced project failure. Information and Software Technology, 54, 866-886.

Yap, C. S., Lim, Y. M., \& Lee, T. H. (2013). Explaining IT outsourcing satisfaction using Domberger's Theory: An SME perspective. Gadjah Mada International Journal of Business, 15 (1), 45-60.

Yin, R. K. (2003). Case study, research design and methods. Thousand Oaks - London - New Delhi: Sage Publication.

Advised by Dana Egerova, University of West Bohemia, Czech Republic

Received: June 04, 2015

Accepted: June 26, 2015

Kaja Prystupa

PhD., Assistant Professor, Koźmiński University, 57 Jagiellońska Street, Warsaw, Poland.

E-mail: kmprystupa@alk.edu.pl

Maciej Rządca

Research Assistant, Koźmiński University, 57 Jagiellońska Street, Warsaw, Poland. E-mail: mrzadca@alk.edu.pl 